\title{
A phytochemical study of bala dwayam (Sida cordifolia \& Abutilon indicum linn.) And clinical evaluation of its moola churna ksheerapaka in Sandhigata vata with special reference to janu sandhi
}

\author{
Research Article
}

\section{Manna Mathew ${ }^{1}$, Changade Jayshree², Varghese Jibi Thankachan ${ }^{3 *}$, Gangale Nilima ${ }^{4}$}

\author{
1. PG Scholar, 2. Professor and Head, 4. Associate Professor, Department of Dravyaguna, \\ 3. Professor, Department of Kayachikitsa, \\ Dr. D.Y. Patil College of Ayurved \& Research Centre, Dr. D.Y.Patil Vidyapeeth, Pimpri-Pune.
}

\begin{abstract}
Joint pain is a world wide problem. Almost 70 to $80 \%$ of the world population suffer from it. Statistical analysis shows that by the age of 60 to 75 years, $80 \%$ of the population shows radiographic evidences of osteoarthritis. Osteoarthritis of the knee joint is characterised by gradual increase of pain in the joint, 'grating' may be felt or heard on movement. A plain radiograph is the only useful investigation. This may show some typical features of osteoarthritis, namely focal narrowing of joint space, marginal osteophyte, subchondral sclerosis cysts and osteochondral bodies. According to Ayurveda it is coined as Sandhigatavata where in Vata takes on the sandhisthana, it leads to the degeneration of asthi dhatu and decreases shleshaka kapha disturbing the normal structure and functions of the joints involved. As age advances Vatadosha triggers and accelerates dhatukshaya and balakshaya. Sandhigatavata is a madhyama rogamarga vyadhi involving the sandhi marma. Dhatukshaya in highly prevalent in vriddhavastha. Thus the involvement of Marma, Madhyama roga marga, vata dosha and dhatukshaya adds to the kashtasadhyata of the disease.
\end{abstract}

Key Words: Sandhigatavata, Janu Sandhi, Bala, Atibala, Rasayana, Musculoskeletal disorder.

\section{Introduction}

Musculoskeletal disorders are the most commonest self -reported ailment in the community. It has a substantial influence on health and quality of life and impose an enormous burden of cost on the healthcare system. Prevalence of musculoskeletal disorders varies with the change of climatic conditions and geographic region. It also identifies advancing age and female sex as the factors associated with increased incidence of Musculoskeletal pain. Arthritis affects 15\% people i.e. over 180 million people in India. This prevalence is higher than many well known diseases such as diabetes, AIDS and cancer.

Bala (Sida cordifolia Linn.) and Atibala (Abutilon indicum Linn.) both together are called as Bala Dwayam $(1,2,3)$. Qualities of both are nearly identical. Both the Medicinal plants are said to be Vatapittahara. Ksheerapaka refers to medicated milk which is prepared by boiling the milk with drug and water until only milk part remains (4)'. When drugs like Bala and Atibala are added in the preparation of ksheerapaka, it will have an add on effect of nutritional

* Corresponding Author:

Varghese Jibi Thankachan

Professor,

Department of Kayachikitsa,

Dr. D.Y. Patil College of Ayurved \& Research Centre,

Dr. D.Y.Patil Vidyapeeth, Pimpri. Pune. India.

Email Id: vjayu82@gmail.com value along with its medicinal property of Vatapittahara.

\section{Aims and Objectives}

Aim

- To compare the effect of Bala moola churna ksheerapaka and Atibala moola churna ksheerapaka in Janu Sandhigatavata.

\section{Objective}

- To study the disease Sandhigatavata.

\section{Materials and Methods}

\section{Materials}

In this study two herbal drugs and its milk preparations (ksheerapaka) are used.

1. Bala moola (Sida cordifolia Linn.) ksheerapaka Group A

2. Atibala moola (Abutilon indicum Linn.) ksheerapaka-Group B

Table no. 1 - Group A

\begin{tabular}{|c|c|c|}
\hline Drug & Botanical name & Rasa \\
\hline Bala (Root) & Sida cordifolia Linn. & Madhura \\
\hline
\end{tabular}

Table no. 2 - Group B

\begin{tabular}{c|c|c} 
Drug & Botanical name & Rasa \\
\hline Atibala (Root) & Abutilon indicum Linn. & Madhura
\end{tabular}

Standardization \& authentication of raw drugs were done at a standard pharmacognosy laboratory and 
Manna Mathew et.al., Clinical study to evaluate the efficacy of bala dwayam churna ksheerapaka in sandhigatavata

the prepared ksheerapaka was also subjected to phytochemical analysis.

\section{Method of Preparation of Ksheerapaka}

Churna (Coarse Powder)

(1 part $=10$ gms, single dose $)$

\{Group A: Bala

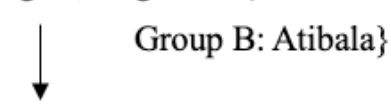

Add 8 parts milk and 32 parts of water in 1-part Churna

Boil the decoction till milk remains in the vessel.

Filter the decoction.

Prepared Ksheerapaka is administered.

Table no. 3 - Dosage schedule

\begin{tabular}{|l|c|c|}
\hline Drug & $\begin{array}{c}\text { Group A } \\
\text { Bala Moola } \\
\text { Ksheerapaka }\end{array}$ & $\begin{array}{c}\text { Group B } \\
\text { Atibala Moola } \\
\text { Ksheerapaka }\end{array}$ \\
\hline Dose & $80 \mathrm{ml}$ & $80 \mathrm{ml}$ \\
\hline Route & Oral & Oral \\
\hline $\begin{array}{l}\text { Sevan } \\
\text { kala }\end{array}$ & $\begin{array}{c}\text { Apana kaal } \\
\text { Morning and evening } \\
\text { before meals }\end{array}$ & $\begin{array}{c}\text { Morning and evening } \\
\text { before meals }\end{array}$ \\
\hline $\begin{array}{l}\text { Duration } \\
\text { Follow } \\
\text { up }\end{array}$ & 30 days & 30 days \\
\hline
\end{tabular}

\section{Ethical Clearance}

Permission of Institutional Ethics Committee was sought before starting the clinical study.

CTRI Registration: CTRI/2019/03/018183

\section{Selection Criteria}

\section{Inclusion Criteria}

- Classical sign and symptoms of Janu Sandhigatavata are Shula, Shotha, Stambha, Sparshaasahyata, Sphutana, Akunchana prasarana vedana etc. at the joints.

- Patients between age group of 45 - 70 years.

\section{Exclusion Criteria}

- Patients below 45 and above 70 years of age.

- Patients with other joints deformities or diseases which are not related to Sandhigatavata, such as Amavata, Vatarakta, fracture of joints, and needs surgical care will be excluded.

- Autoimmune diseases like SLE, Ankylosing Spondylitis.

\section{Withdrawal Criteria}

- If patients develop any adverse effect.

- If patient is not responding to treatment and aggravation of symptoms.

- If patient refuses to continue with the treatment.

\section{Informed Consent}

Written valid, informed consent of the patient was taken prior to the enrolment of the trial.

\section{Criteria of assessment}

A.Parameters for Subjective criteria

1. Pain

No pain - 0

Mild pain -1

Moderate pain but no difficulty in walking - 2

Slight difficulty in walking due to pain - 3

Severe difficulty in walking - 4

2. Sandhigraha (stiffness)

No stiffness - 0

Mild stiffness -1

Moderate stiffnesss -2

Severe difficulty due to stiffness - 3

Severe stiffness more than 10 minute -4

3. Akunchanprasaranjanya Vedana (Pain during flexion \& extension)

No pain - 0

Pain without winching of face - 1

Pain with winching of face - 2

Prevent complete flexion - 3

Does not allow passive movement - 4

4. Sparsha Asahyata (Tenderness)

No tenderness - 0

Patient sayes tenderness - 1

Winching of face on touch - 2

Does not allow to touch the joint - 3

5. Sandhisphutuna (Crepitus)

No crepitus - 0

Palpable crepitus - 1

Audible crepitus - 2

\section{Objective Criteria}

- Range of Movements will be measured with the help of Goniometer.

- WalkingTest

- Climbing Stair Test

- WOMAC Scale

- Visual Analogue Scale (VAS) will be added in the case sheet for assessment of pain.

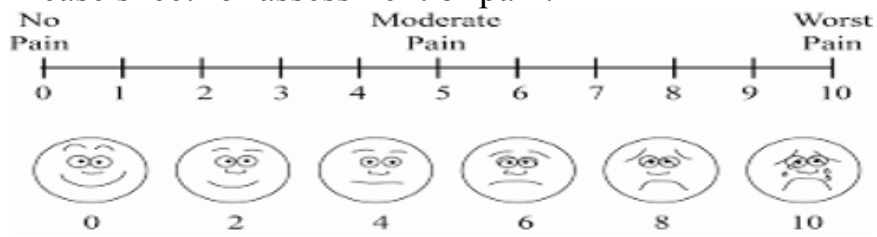

Table no. 4 - Visual Analogue Scale (Pain)

\begin{tabular}{l|c|c|c|} 
Pain & Range & Grade \\
\hline No Pain & & 0 & 0 \\
\hline Mild Pain & $1-3$ & & 1 \\
\hline Moderate Pain & $4-6$ & & 2 \\
\hline Severe Pain & $7-9$ & & 3 \\
\hline Worst Pain & & 10 & 4
\end{tabular}

Table no. 5 - Range of Movements Flexion of knee joint

\begin{tabular}{|c|c|c|}
\hline Range of Movement & Movement Angle & Grade \\
\hline None & $>130$ & 0 \\
\hline Mild & $130-120$ & 1 \\
\hline Moderate & $120-110$ & 2 \\
\hline Severe & $110-100$ & 3 \\
\hline Extreme & $100-90$ & 4 \\
\hline
\end{tabular}


Table no.6 - Climbing Stair Test Time taken to climb 10 steps

\begin{tabular}{|c|c|c|}
\hline Criteria & Time & Grade \\
\hline Easily & 0 & 0 \\
\hline With mild difficulty & $0-30 \mathrm{sec}$ & 1 \\
\hline Moderate & $30 \mathrm{sec}-1 \mathrm{~min}$ & 2 \\
\hline With marked difficulty & $1 \mathrm{~min}-1 \mathrm{~min} 30 \mathrm{sec}$ & 3 \\
\hline Impossible & $1 \mathrm{~min} 30 \mathrm{sec}-2 \mathrm{~min}$ & 4 \\
\hline
\end{tabular}

Table no. 7 - Walking Test Time taken to walk $30 \mathrm{mts}$

\begin{tabular}{|c|c|c|}
\hline Criteria & Time & Grade \\
\hline Easily & 0 & 0 \\
\hline With mild difficulty & $0-30 \mathrm{sec}$ & 1 \\
\hline Moderate & $30 \mathrm{sec}-1 \mathrm{~min}$ & 2 \\
\hline With marked difficulty & $1 \mathrm{~min}-1 \mathrm{~min} 30 \mathrm{sec}$ & 3 \\
\hline Impossible & $1 \mathrm{~min} 30 \mathrm{sec}-2 \mathrm{~min}$ & 4 \\
\hline
\end{tabular}

Table no. 8- WOMAC Score Grading

\begin{tabular}{|c|c|c|}
\hline None & 0 & 0 \\
\hline Mild & $0-24$ & 1 \\
\hline Moderate & $25-48$ & 2 \\
\hline Severe & $49-72$ & 3 \\
\hline Extreme & $73-96$ & 4 \\
\hline
\end{tabular}

\section{Table no. 9 - Criteria for overall assessment

\begin{tabular}{|c|c|}
\hline Cured & $100 \%$ relief in sign and symptoms \\
\hline Best Improvement & $\begin{array}{c}>75 \% \text { and }<100 \% \text { relief in sign and } \\
\text { symptoms }\end{array}$ \\
\hline Moderate Improvement & $\begin{array}{c}>50 \% \text { and }<75 \% \text { relief in sign and } \\
\text { symptoms }\end{array}$ \\
\hline Mild improvement & $\begin{array}{c}>25 \% \text { and }<50 \% \text { relief in sign and } \\
\text { symptoms }\end{array}$ \\
\hline Unchanged & $<25 \%$ relief in signs and symptoms \\
\hline
\end{tabular}

\section{Lab. Investigations}

1. Routine investigations : CBC, Sr. Calcium

2. X-Ray of Knee Joint AP/ Lat view of patients will be done, if necessary.

\section{Observations}

The distribution of patients in both the groups showed a maximum number of male patients in the age group of 45-50 years having upper middle socio economic status with more of service going people. Majority of the patients had gradual and progressive involvement of knee joint pain with vatapitta prakruti along with madhyam sara samhana dashavidha pariksha bhavas.

\begin{tabular}{|c|c|c|c|c|c|c|c|}
\hline Sr.No. & $\begin{array}{l}\text { Effect of Treatment on } \\
\text { Symptoms }\end{array}$ & Group & $\begin{array}{l}\text { Difference } \\
\text { In Means }\end{array}$ & $\begin{array}{c}\text { Standard Deviation } \\
\text { ( S.D.) }\end{array}$ & SEM & $\mathbf{t}$ & p value \\
\hline \multirow[t]{2}{*}{1} & \multirow[t]{2}{*}{ Effect on Sandhishula } & A & 1.333 & 0.547 & 0.0998 & \multirow[t]{2}{*}{1.254} & \multirow[t]{2}{*}{0.215} \\
\hline & & B & 1.133 & 0.681 & 0.124 & & \\
\hline \multirow[t]{2}{*}{2} & \multirow[t]{2}{*}{ Effect on Sandhi Shotha } & A & 0.333 & 0.547 & 0.0998 & \multirow[t]{2}{*}{3.120} & \multirow[t]{2}{*}{0.003} \\
\hline & & B & 0.800 & 0.610 & 0.111 & & \\
\hline \multirow[t]{2}{*}{3} & \multirow[t]{2}{*}{ Effect on Sandhigraha } & A & 0.667 & 0.802 & 0.146 & \multirow[t]{2}{*}{0.348} & \multirow[t]{2}{*}{0.729} \\
\hline & & B & 0.600 & 0.675 & 0.123 & & \\
\hline \multirow[t]{2}{*}{4} & \multirow{2}{*}{$\begin{array}{l}\text { Effect on Akunchana } \\
\text { Prasaran Vedana }\end{array}$} & A & 0.667 & 0.661 & 0.121 & \multirow[t]{2}{*}{2.926} & \multirow[t]{2}{*}{0.005} \\
\hline & & B & 1.133 & 0.571 & 0.104 & & \\
\hline \multirow[t]{2}{*}{5} & \multirow[t]{2}{*}{ Effect on Sparshasahatva } & A & 0.433 & 0.568 & 0.104 & \multirow[t]{2}{*}{0.0333} & \multirow[t]{2}{*}{0.820} \\
\hline & & B & 0.400 & 0.563 & 0.103 & & \\
\hline \multirow[t]{2}{*}{6} & \multirow[t]{2}{*}{ Effect on Sandhisphutana } & A & 0.400 & 0.498 & 0.0910 & \multirow[t]{2}{*}{2.380} & \multirow[t]{2}{*}{0.021} \\
\hline & & B & 0.733 & 0.583 & 0.106 & & \\
\hline \multirow[t]{2}{*}{7} & \multirow{2}{*}{$\begin{array}{l}\text { Effect on Range of } \\
\text { Movement }\end{array}$} & A & 0.667 & 0.547 & 0.0998 & \multirow[t]{2}{*}{0.249} & \multirow[t]{2}{*}{0.804} \\
\hline & & B & 0.633 & 0.490 & 0.0895 & & \\
\hline \multirow[t]{2}{*}{8} & \multirow[t]{2}{*}{ Effect on Walking Test } & A & 1.567 & 0.728 & 0.133 & \multirow[t]{2}{*}{0.549} & \multirow[t]{2}{*}{0.585} \\
\hline & & B & 1.467 & 0.681 & 0.124 & & \\
\hline \multirow[t]{2}{*}{9} & \multirow{2}{*}{$\begin{array}{l}\text { Effect on Climbing stair } \\
\text { Test }\end{array}$} & A & 1.900 & 0.712 & 0.130 & 1.270 & 0.209 \\
\hline & & B & 1.667 & 0.711 & 0.130 & & \\
\hline 10 & Effect on VAS & A & 1.167 & 0.379 & 0.0692 & 2.660 & 0.010 \\
\hline & & B & 1.500 & 0.572 & 0.104 & & \\
\hline 11 & Effect on WOMAC Scale & A & 1.067 & 0.254 & 0.0463 & 1.523 & 0.133 \\
\hline & & B & 1.200 & 0.407 & 0.0743 & & \\
\hline
\end{tabular}

Table no. 11: Showing the Overall Effect of Treatment Group A \& Group B on basis of VAS

\begin{tabular}{|c|c|c|c|c|}
\hline Effect & No. of patients Group A & $\mathbf{\%}$ & No. of patients Group B & $\mathbf{\%}$ \\
\hline Cured & 0 & 0 & 1 & 3.33 \\
\hline Best improvement & 10 & 33.33 & 18 & 23.33 \\
\hline Moderate improvement & 12 & 40 & 4 & 60 \\
\hline Mild improvement & 8 & 26.66 & 0 & 13.33 \\
\hline Unchanged & 0 & 0 & & 0 \\
\hline
\end{tabular}


Manna Mathew et.al., Clinical study to evaluate the efficacy of bala dwayam churna ksheerapaka in sandhigatavata

Graph no: 1 Showing the Overall Effect of Treatment

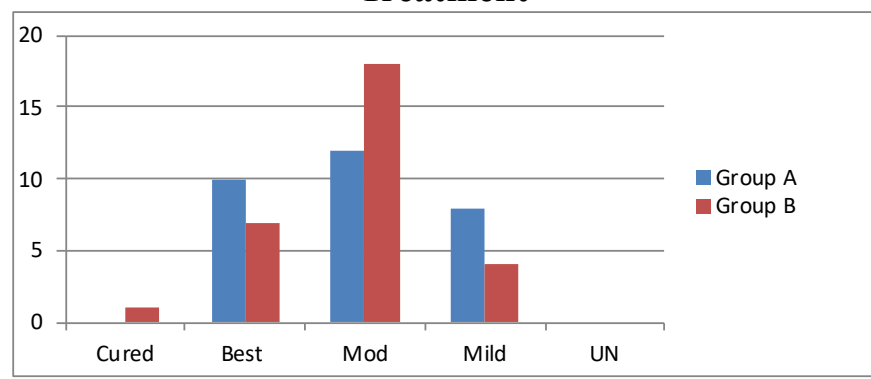

\section{Comparison of Over All Effect of Treatment in both the Groups A \& B}

On comparison between both the Groups A \& B on overall effect of treatment on basis of VAS showed that 3.33\% from Group B had attained full cure rate, while $33.33 \%$ and $23.33 \%$ patients attained best improvement in Group A and Group B respectively. Moderate improvement was experienced by $40 \%$ in Group A and 60\% in Group B while 26.66\% and $13.33 \%$ patients received mild improvement in Group A and Group B respectively. Group A and Group B both showed statistically significant results in nearly all the parameters accessed. In the parameters of sandhi shula, sandhi graha sparshasahatva Group A had significant results while in parameters of sandhi shotha, akunchana prasaran vedana and sandhisputana Group B had significant results. Considering VAS scale and WOMAC scale Group B had an edge over to Group A statistically with $p$ value 0.010 and $p$ value 0.133 respectively. However the dominance of Group B ie. the patients who received Atibala moola ksheerapaka presumed to have received better results than Group A ie the patients who received Bala moola ksheerapaka in comparison to the over all effect of treatment.

\section{Discussion}

On the basis of the above mentioned results, it is clear that Bala moola Ksheerapaka and Atibala moola Ksheerapaka produced significant improvement on various symptoms and signs including pain, tenderness, stiffness and swelling. Marked improvement in WOMAC score was also significant. But there was not much significant changes observed in X-rays and Sr. calcium levels of pre and post treatment done. Besides the treatment was found to be safe, palatable and well tolerated. No obnoxious side effects were observed.

\section{Conclusion}

Bala is the most common drug mentioned in many preparations of Ayurvedic formulations and widely described with its classification in almost all ancient classical texts. In the present study Bala and Atibala both belonging to Malvaceae family are chiefly considered as sources of Bala with respect to different aspects of drug assay. Pharmacognostical study reveals almost common root anatomy with slight distinguishing characters.

Milk (Ksheer) is easily available and described as as jivana, brimhana, nitya rasayana and pathyatama. (5)Thus it is good in prevention and curative aspect of many disorders, especially those having chronic nature. Milk has properties similar to that of ojas and hence it improves immunity and body defense mechanism. Milk contains Vitamins, fat. Protein carbohydrate, minerals etc. which is needed for physical and mental well-being. Ksheerapaka kalpana or medicated milk is an ayurvedic dosage form and is been potentially used as a medicine by combining it with different herbs which nourishes the tissues and have more anabolic effects.

Sandhigata vata is a degenerative disorder generally occurring in the adults. As the age increases Vata with its ruksha khara guna afflicts the joint causing more degeneration of the bone as well as the cartilage and the surrounding tissues. The synovial fluid is also reduced which causes the rubbing of the bones and the disease progresses with pain and reduced movements of the joint. Early diagnosis of this disease, foundation of remedial measures to prevent debilitating orthopedic problem and giving support and guidance to the family members helps to definitely improve the prognosis for the patients suffering from sandhigatavata

Thus it may be concluded that the research study of Bala Moola Ksheerapaka and Atibala Moola Ksheerapaka is an effective and safe regimen in the symptomatic relief of Janu Sandhigatavata (knee osteoarthritis).

\section{Acknowledgement}

Department of Dravyaguna and Department of Kayachikitsa of Dr. D.Y.Patil Vidyapeeth, Pune

\section{References}

1. Manna Mathew -'Preliminary Standardization of Bala Moola Ksheerapaka and Atibala Moola Ksheerapaka - Two Herbal Formulations for Sandhigatavata, Vol 13, Issue 3, 2020,IJAPC, page no 378-388

2. Sastry J.L.N, DravyagunaVijana, Vol-II, Chaukhambhaorientalia, Varanasi, Reprint edition 2012, page no 87.

3. Sastry J.L.N, DravyagunaVijana, Vol-II, Chaukhambhaorientalia, Varanasi, Reprint edition 2012, page no 91.

4. Himasagara Chandramurthy, Sarangadhara Samhita, edition 2010, Varanasi, Chaukhambha Sanskrit Series office, page no 139.

5. Jadavji Trikamji Acharya, Charaka Samhita, with commentary of Chakrapanidatta, edition 2007, Varanasi, Chaukhamba Orientalia, page no 165. 